\title{
THE ENGLISH TRANSLATION OF GRAZIA DELEDDA'S LA MADRE AND THE RELEVANCE OF CULTURE IN TRANSLATING LANDSCAPE METAPHOR
}

\author{
Eleonora Fois 1 \\ ${ }^{1}$ University of Cagliari, Cagliari, Italy
}

\begin{abstract}
This contribution explores the impact of the translator's cultural framework on the translation of landscape-related metaphor via a contrastive analysis of La madre, by the Sardinian Nobel Laureate in Literature Grazia Deledda, and its 1922 translation (The Mother) by Mary Steegman. Culture influences the vision of nature in providing distinct norms and ideologies about how people relate to others and the natural world. Deledda's language of space originated from a subjective perception, and so did her use of space-related metaphors. In translation, however, the negotiation of meaning involving landscape metaphors becomes more complex. The source author's subjective perception and individuality overlaps with the translator's subjectivity, which impacts on the target text with political and ideological consequences. This contribution examines in particular anthropomorphism and the relationship between metaphor and simile. It will be argued that the translator's interpretation can reshape relationship and the target readers' understanding of that landscape. The analysis will be based on Conceptual Metaphor Theory (CMT) and Mandelblit's Cognitive Translation Hypothesis (1995). Ecostylistics will provide a further framework, to examine the patterns which uncover the translator's approach with regards to nature and landscape.

Keywords: Anthropomorphism; Metaphors; Simile; Literary Translation; Ecostylistics
\end{abstract}




\title{
A TRADUÇÃO EM INGLÊS DE LA MADRE, DE GRAZIA DELEDDA, E A RELEVÂNCIA DA CULTURA NA TRADUÇÃO DA METÁFORA DA PAISAGEM
}

\begin{abstract}
Resumo: Este artigo explora o impacto da estrutura cultural do tradutor na tradução da metáfora relacionada à paisagem por meio de uma análise contrastiva de La madre, de Grazia Deledda, Prêmio Nobel de Literatura, e a tradução de 1922, The Mother, realizada por Mary Steegman. A cultura influencia a visão da natureza ao fornecer normas e ideologias distintas sobre como as pessoas se relacionam com os outros e com o mundo natural. A linguagem do espaço de Deledda se originou de uma percepção subjetiva, assim como seu uso de metáforas relacionadas ao espaço. Na tradução, no entanto, a negociação de significado envolvendo metáforas da paisagem se torna mais complexa. A percepção subjetiva e a individualidade do autor do original se sobrepõem à subjetividade do tradutor, que impacta o texto de chegada com consequências políticas e ideológicas. Esta contribuição examina em particular o antropomorfismo e a relação entre metáfora e símile. Argumentar-se-á que a interpretação do tradutor pode remodelar o relacionamento e a compreensão dos leitoresalvo desse cenário. A análise será baseada na teoria conceitual de metáfora e na hipótese de tradução cognitiva de Mandelblit (1995). A ecoestilística fornecerá uma estrutura adicional para examinar os padrões que revelam a abordagem do tradutor em relação à natureza e paisagem.
\end{abstract}

Palavras-chave: Antropomorfismo; Metáforas; Símiles; Tradução Literária; Ecoestilística

\section{Introduction}

In narrative texts, landscape description has an ekphrastic status that goes beyond setting the scene (Eggan 398): the real-world space often serves as context and referent. To understand the spatial description, the reader needs to envisage a "context of situation" (Werth 26), a text world which is negotiated by the author and the reader through the discourse. The text world discourse is culturally and socially situated, for the language of its participants is deeply influenced by their experience (Gavins and Lahey 3). Thus, conceptual constructs involving landscape need to be supported by shared and relevant 
knowledge, for every landscape carries with it a degree of cultural meaning often subconsciously absorbed: what lies beyond one's cultural experience might be unsettling and threatening (Atkins 1).

One of the ways to fully express ideas related to landscape and human experience is metaphor (Anderson et al. 9): the conceptual metaphor LANDSCAPE IS A BODY, for instance, is considered a linguistic universal, and "essential in the Western world" (Hough 13). Anthropomorphic expressions, for instance, are particularly important to understand the cultural interpretation of the landscape. Culture influences the anthropomorphic vision of nature in providing distinct norms and ideologies about how people relate to others and the natural world (Epley et al. 867).

The negotiation of meaning involving landscape metaphors in the text world, then, becomes more complex once translation is involved: the translator is required to penetrate and understand a foreign - and sometimes unfamiliar - cultural framework and then project it onto their own culture and experience. This contribution then focuses on the translation of landscape-related metaphor. The strategies will be investigated via a contrastive analysis of Sardinian Nobel Laureate in Literature Grazia Deledda's novel La madre ${ }^{1}$ and its 1922 translation (The Mother) by Mary Steegman. As Deledda's best-known work outside Italy (Magill 332), La madre offers a good vantage point to observe the translated Sardinian landscape in its intercultural perception.

Sardinian nature and landscape, whose importance was among the reasons for Deledda's Nobel Prize (Miccinesi 20), were fundamental bricks of Deledda's authorial identity. The strong autobiographical mark of Deledda's writing also involved accurate landscape descriptions, shaped by her subjective perception and

\footnotetext{
${ }^{1}$ Paulo, the priest of the small village of Aar, falls in love with a woman from the village, Agnese, who returns his affection. When his mother, Maria Maddalena, finds out, she urges him to put an end to the affair. Despite his initial doubts, Paulo decides to give up Agnese, who then threatens to expose him in front of all his parishioners. In the final scene, set in the village church, Agnese relents, Paulo regains his faith but the mother, weakened by the consuming pain, dies in silent agony.
}

Cad. Trad., Florianópolis, v. 40, n 2, p. 112-130, mai-ago, 2020. 
inspired by existing, recognizable places (Ruschioni 445). In translation, however, the source author's and individuality overlaps (or even clashes) with the translator's subjectivity: Steegman's domesticating approach to the foreign landscape of Sardinia (Fois, forthcoming) brought to light a distinct ideological approach to the peripheral culture.

In the scarcity of studies concerning Deledda's language of landscape (Mortara Garavelli; Johnson), a specific focus on metaphor is even rarer. It will be argued here that the translator's interpretation can re-shape the features of landscape-related metaphor in the Target Text (TT) and consequently the target readers' understanding of that landscape. The analysis will be based on Conceptual Metaphor Theory (CMT) and Mandelblit's Cognitive Translation Hypothesis (1995). The cognitive approach helps locate the highly cultural imprint of the models through which reality is perceived. The same models are involved in metaphor creation in the source culture and translation in the target culture. Ecostylistics will provide the second framework for the translational analysis. Ecostylistics explores the stylistic and ideological underpinning for how the physical environment is presented in texts (Douthwaite et al. 2). It studies how a text comes to convey a certain stance and helps raise awareness of the ways in which languages emphasize and de-emphasize aspects of the environment (Fill and Muhlhauser 3). Despite the lack of studies which apply ecostylistics to translation (Zerkowitz's the only one, to the author's knowledge), ecostylistics is ideal to analyse those patterns in literary texts which are generally excluded from ecolinguistic consideration, but which still uncover the translator's approach with regards to nature and landscape. Finally, it helps reveal how a certain culture encodes the dilemma between the desire of contact with the Other and the "challenging reality of difference" (Cronin 133).

Particular attention will be given to:

1. The strategies employed in translating landscape metaphor. The focus will be on detecting whether the domains in 
Source Text (ST) and TT overlap and the way in which the TT metaphor was transformed.

2. The translation of anthropomorphic metaphor. The metaphorical use of anthropomorphism is a textual embodiment of the symbolic relationship between landscape and cultural identity (Lahey 156), so it represents a valid element to test the intercultural approach to nature in translation.

Before presenting the contrastive analysis, the main features of metaphor will be introduced, along with the main problems concerning metaphor translation.

\section{Metaphor Translation}

Marking a rupture with the vision of metaphor as a merely linguistic phenomenon, Conceptual Metaphor Theory (CMT) describes metaphor as "primarily a matter of thought and action, and only derivatively a matter of language" (Goatly 153). Metaphors help define one domain of experience (a target domain) in terms of another (a source domain) (Lakoff and Johnson 5; Schäffner 1258), capitalizing on cultural properties which in turn rely on the encyclopaedic knowledge of the world (Eco 407). From this perspective, there can be consistent and conflictual metaphors. The former are so fused into the common language that the speakers are hardly aware of them. The latter are textual interpretations of complex meanings that contain a conceptual conflict (Prandi (a) 311), such as the concept of nature as a human being, found in anthropomorphic metaphors. From a cognitive perspective, anthropomorphism belongs to the LANDSCAPE IS A PERSON/ CHARACTER mapping (Lahey 162). Anthropomorphism derives in fact from projecting humanlike characteristics, motivations, intentions, and emotions on non-human agents. Anthropomorphism results from an inference about unobservable traits of a nonhuman entity which go beyond a mere description of observable or imagined actions ("the dog is affectionate vs the dog loves me" (Epley et al. 865). 
Particularly relevant in translation analysis is also the relationship between metaphor and simile, namely, whether metaphors can simply be considered as elliptic similes. Despite being overlooked by translators (Prandi (a) 322), the decision of translating a metaphor with a simile needs to be thoroughly understood. According to Aristotle, there is only a slight difference between metaphor and simile (qtd in Stern 229). The two tropes display a common background of similarity and the same perlocutionary force - they both ask the readers to compare (Bridgeman 65). Metaphor and simile would differ only by the occurrence of "like" (Stern 330) which might be interpreted as a grammatically superficial and a semantically insignificant item.

There is, however, a cognitive distance between the two tropes. The occurrence - or the absence - of the word "like" is an indicator of the cognitive process underlying the choice between the two tropes (Aisenman 46): metaphors function like categorization statements and similes more like comparison statements (Chiappe et al. 85; Prandi (b), 99). Metaphors equate heterogeneous ideas transferring a conflicting concept into an alien conceptual domain, whereas "simile compares different things each rooted in its own conceptual area: predicating similarity, simile assumes differences, and avoids conceptual conflict" (Prandi (a) 322). The different syntactic form between metaphor and simile would reflect the contradictory content of the former and the explanatory power of the latter (Bridgeman 70). As a consequence, the translator might superimpose their inferences on the conflictual meaning: the vagueness and the conflict of the metaphor are reduced because it is reformulated it as a simile, setting a monodimensional comparison in which cross-mapping is more focused and without rich inferences (Dancygier and Sweetser 148).

Communicating resemblance through metaphor, which is, in fact, an assertion of identity, is far more committing than using a simile (Alderman 49), whereas the attributive features, the "mere appearance" (Alderman 49), especially when both source and target domains are concrete (Gibb and Wales 230), can be adequately 
expressed by a weaker linguistic representation of resemblance namely, the simile.

Metaphors, whether investigated from a linguistic or cultural perspective, pose a challenge to the never totally dismissed notion of equivalence. From a cognitive point of view, the mental representation of the real world necessary to understand and translate a metaphor is the product of a cognitive process realized thanks to the use of language and moulded by a specific cultural dimension. Cultural beliefs and values are then to be taken into account as agents which shape the way speakers (and translators) see the world: the overlapping of experience determines the possibility to successfully translate a metaphor. Languages which are genetically, historically and culturally close display high comparability in the distribution of metaphor domains (Steen 12).

Literal translations of metaphors become pointless. The image in the ST cannot always be retained in the TT because the associations triggered by the ST metaphor get lost, or the image that is attached to the metaphor is unknown in the Target Language (Schäffner 1255). Mandelblit's "Cognitive Translation Hypothesis" reads the process of translating metaphor in terms of Similar Mapping Condition and Different Mapping Condition. Metaphorical expressions take more time and are more difficult to translate if they exploit a cognitive domain different from that of the equivalent target language expression. The linguistic result of a similar mapping condition in the TT is often an equivalent metaphor or - in the worst case - a simile. The result of a different mapping condition, however, is open to many possibilities, of which rendering the ST metaphor into a TT metaphor is the least likely. Thus, a metaphor might be rendered into a simile, a paraphrase, a footnote, an explanation or - as a last resort - it can be omitted (Al Zoubi et al. 234). No attention is paid to the textual and interpretative consequences of transforming metaphor as simile.

In terms of strategies:

1. A conceptual metaphor is identical in ST and TT at the macro-level but not at the micro-level; 
2. Structural components of the base conceptual schema in the ST are replaced in the TT by expressions that make entailments explicit.

3. A metaphor is more elaborate in the TT.

4. ST and TT employ different metaphorical expressions which can be combined under a more abstract conceptual metaphor.

5. The expression in the TT reflects a different aspect of the conceptual metaphor (Schäffner 1267). The possibility of omission of the metaphor altogether is not included.

Translating metaphors is not seen as a crucial issue in the negotiation of the identity of the TT. The following analysis aims at investigating the impact that the translation of metaphors can have on the TT in terms of cultural understanding of the landscape.

\section{Analysis}

The first part of the analysis (examples 1 - 3) will focus on the strategies for translating landscape metaphor; the second part (examples 4-7) will focus on the translation of anthropomorphic references. The parts in italics indicate the metaphors analyzed, while other nouns and expressions still connected to the landscape and helpful in supporting the analysis will be mentioned in the discussion.

\section{1}

ST E ritornò su verso la chiesa. Le straducole del paesetto erano deserte; [...] sul cielo chiaro di settembre passava una placida greggia di nuvolette bianche (64).

TT He turned and climbed up again towards the church. The village seemed almost deserted; [...] little white clouds floated across the clear September sky like a peaceful flock of sheep (107).

Steegman shows a preference for generalization. The omission of the noun "straducole" - "small streets" - and "paesetto" - 
"small village"- align with the systematic omission of alterations concerning elements of the landscape of human creation (Fois, forthcoming). The choice of translating the verb phrase "erano" - "they were"- with "seemed" transforms the certainty of the ST into perception in the TT. The image of the metaphor involving the clouds - "placida greggia" - in the ST is turned into a simile in the TT via recategorization. In terms of content, the depiction of clouds as visually reminiscent of a flock of sheep is preserved, so the choice of the simile does not appear to depend on a case of different domains. The stylistic effect, however, is different, for the ST is more visually expressive than the TT.

ST Un attimo; e si accorse con terrore che ricadeva nell'incubo. Non era salvo ancora: bisognava attraversare un'altra notte, come un ultimo tratto di mare burrascoso (123).

TT An instant more, and he perceived with terror that the nightmare obsessed him still. He was not safe yet, there was another night to be got through, as the voyager crosses a last stretch of turbulent sea (212).

The first sentence of the TT recategorizes "nightmare", which becomes the subject of the subordinate clause. The verb "ricadere" "to fall again" - is translated with "obsessed", as a result of Steegman's autonomous interpretation. In the second sentence, the simile is amplified by the addition of a new subject - "voyager"- and a new verb - "crosses". The ST brings together the night and the sea, both quiet and stormy at times. Steegman's amplification instead extends the sense of the metaphor and pivots around Paulo, now explicitly compared to a voyager. The perspective has shifted and so has the readers' attention.

\section{3}

ST Gli ontani in fila davanti al parapetto della piazza della chiesa, si sbattevano furiosi al vento, neri e sconvolti come mostri (7). 
TT The elder trees which grew along the parapet of the piazza before the church were bending and tossing furiously in the wind, black and shapeless monsters in the gloom (7).

The simile in the ST is translated with a metaphor in the TT. The noun "mostri" - "monsters" is recategorised as an adjunct and modified by two adjectives, the first of which is translated directly: "neri" - "black". Deledda's choice of words is descriptive and expressive at the same time, helping to perceive the trees as alive. In Italian, "Sconvolto", the second adjective defining the wind in the ST, can mean "squassato dal vento" - "shaken violently by the wind" - as well as "in preda a una profonda emozione" "fell prey to a strong emotion" ("sconvolto"). Steegman translates "sconvolto" with the premodifier "shapeless": a noticeable shift, oriented towards neutrality, from the set of ST adjectives.

The translation of the noun phrase "lontani . . . in fila" in the first sentence is equally revealing of the way nature tends to be neutralized. Because of its collocation, in fact, in Italian "in fila" reminds of order and obedience: soldiers in line or children waiting for the bell of the last school hour to ring. It is strongly evocative of human situations, now somehow projected onto natural elements. In the TT, however, the collocation, "grew along", while still featuring an active verb, places the noun "trees" in a neutral position.

\section{4}

ST [...] poi Paulo si trovò solo, tra la fiammella tremula del lume e la luna che guardava dal finestrino [...] (147).

TT [...] and Paul found himself alone, between the flickering flame of the oil lamp and the calm splendour of the moon that shone in through the high window [...] (149).

Here, the chance of creating a direct translation of the anthropomorphic reference is missed. The underlying conceptual framework in the ST is that the moon behaves like a human being and "looks through the window", whereas the TT features a verb 
which normally occurs with the noun "moon". The amplification, not supported by linguistic material in the ST, clearly shows the translator's interference with the ST original structure. The amplification of the noun phrase in the TT has some stylistic repercussions: "calm splendour of the moon" creates syntactic parallelism with the "flickering flame of the oil lamp". Steegman took some stylistic initiative, but the choice of words is interesting. The premodifier "calm" refers to "the mind, feelings, or demeanour", and it can also be used in collocates with sea, water and air, as seen in the British National Corpus ("calm"). An adjective which commonly describes natural elements was employed in an unusual position. While omitting the anthropomorphic reference, Steegman appears to be opting for a compensating strategy more suited to her interpretation of the possible level of "humanization" in nature. There still appears to be a case of Different Mapping Condition, because the anthropomorphic reference and the "active" representation of nature are gone: a compensating strategy employing a different metaphorical expression more suited to the target culture tries to reproduce the effect of the ST.

\section{5}

ST Nel paesetto già più non si vedeva un lume, un filo di fumo. Dormivano, le povere casette arrampicate come due file di pecore su per la china erbosa [...] (6-7).

TT In the village itself not a light was to be seen, nor even a thread of smoke. They were all asleep by now in the povertystricken cottages, which clung to the grassy hill-side like two rows of sheep [...] (7).

In the ST the houses are anthropomorphised and interpreted as living beings now asleep, but the TT omits the metaphor and the noun phrase "the houses" loses prominence by being turned into an adjunct. The image of the simile "come due file di "pecore"

${ }^{2}$ https://www.english-corpora.org/bnc/

Cad. Trad., Florianópolis, v. 40, n 2, p. 112-130, mai-ago, 2020. 
- "like two rows of sheep" - is kept, which suggests a case of Similar Mapping Condition. However, it is worth noticing the shift from "arrampicare" 3 , directly translatable as "to climb" - "to raise oneself by grasping or clinging, or by the aid of hands and feet" ("climb"), which implies height, to "cling"- "to adhere together in a stiff or firm mass" ("cling"). The action is different and guides the reader towards a mental representation of a less steep landscape.

\section{6}

ST Il vento gli rubava le parole di bocca e le sperdeva lontano (15-16).

TT But his words were lost in the shrill whistling of the wind (24).

In the ST, the wind performs the unmistakably human action of "stealing". The agentivity of the wind is not acknowledged and consequently not reproduced in the TT, where the wind loses prominence and becomes an adjunct. The shift from active to passive voice, with a consequent change of subject, also weakens the presence of the wind. Steegman preserved the expected collocate with wind ("whistle") but the addition of shrill, however literary in tone and usually found with "wind' ("shrill"), however literary in tone and usually found with 'wind', manages to evoke human features ${ }^{4}$.

\section{7}

ST Si era anche allora di primavera, ma tutta la vallata sembrava d'un tratto ripresa dall'angoscia invernale; ogni foglia si torceva, gli alberi si piegavano e pareva guardassero di qua e di là spauriti le nuvole che salivano rapide nere e lucenti da tutte le parti dell'orizzonte [...] (15-16).

3 "salire aggrappandosi, detto di persone o d'animali, e per estens. di piante o altro" (to go up by climbing, used for people and animals, 4 "Of voice, sound: Of a sharp high-pitched piercing tone" 
TT It had been springtime then, too, but the whole valley seemed to have slipped back into the grip of winter. Leaves were blown hither and thither, the trees bent before the blast, leaning one against another, as though gazing fearfully at the battalions of black clouds driving rapidly across the sky from all parts of the horizon [...] (24).

This excerpt exemplifies Deledda's humanization of the Sardinian landscape, which feels the "angoscia" - "anguish", whereas the TT features "grip", a frequent collocate of winter. Moreover, there is a vivid image of pain in the reflexive verb "torcersi", not present in the TT where the passive voice "were blown" deprives the leaves of their agentivity. However, the equally human reference in the adjective "spauriti", which reminds of helpless children, was preserved and translated with the adverb "fearfully".

The "battalions" of black clouds conceptualize the sky as a battlefield: the simile in the ST becomes a metaphor in the TT, also featuring recategorization of elements - "nuvole" becomes a postmodifier - and the omission of the verb phrase "andavano le une contro le alter" - "went one against the other". Compensation in terms of anthropomorphism can be found in the addition of one metaphor not found in the ST: the leaves (described through a metonymy, "the tender green") are "bruised" because they are as fragile and delicate as human skin.

\section{Conclusions}

The analysis showed that the translation of metaphor is heavily dependent on the translator's interpretative framework. In the ST, all the landscape-related metaphors reinforce the idea of a universe shared by the narrator, the characters, and ultimately the reader. In this sense, the choice between metaphor and simile also impacts on the perception of the narrator. In Steegman's translation, the use of the simile contributes to creating a narrator who smooths the impact of foreignness on the target reader, while Deledda's narrator is emotionally involved and completely immersed in the text world. 
Metaphor and simile are grounded in similarity and analogy, but the literal comparison embedded in the simile lacks the suggestive power and the effectiveness of a metaphor (Lakoff and Turner 133). This explains why Deledda used metaphor in describing a landscape so markedly personal to her, whereas Steegman, who interpreted the metaphor in terms of physical resemblance but could not perceive the deeper cultural involvement, opted for a simile.

Anthropomorphic metaphors are particularly recurring in $L a$ madre, where the landscape is explicitly described as a living and active agent: anthropomorphism underlies the vision of the natural landscape as a moral agent worthy of respect (Epley et al. 870). The anthropomorphic references, however, are reduced to a minimum in the TT. According to Fill and Mühlhäusler, the anthropocentrism of language accentuates the distance between humans and the rest of creation (5), predisposes readers to a certain perception of actions and, in translation, moulds the understanding of the source culture as well as uncovering the (more or less conscious) vision of the relationship between nature and human beings in the target culture. In Steegman's translation, nature mainly features as a narrative tool to highlight the characters' psychological development.

The strategies for translating metaphor reflect transform the TT narrator, who displays a more detached and neutral stance. It appears that Steegman tried to bridge that cultural gap for fear of compromising the reception of the novel, losing the notion of 'categorical assertions' (Glucksberg and Haught 361) through which the ST narrator sees the world, and conceptually creates reality. The deeper level which gives nature the label of character in its own way and allows to understand the author's (and also narrator's) deeper connection to nature fails to be conveyed. The growing distance between narrator and readers in the TT is incompatible with the impression of a shared universe that Deledda created in her ST.

The more crucial the role played by a metaphor in shaping the $\mathrm{ST}$, the more its reproduction or recreation should be a dominant in the strategy (Newmark 85). The preservation of the metaphor 
is nonetheless highly dependent on the overlapping of cultural framework and the either domesticating or foreignizing approach chosen by the translator. This contribution demonstrated that neutralizing the metaphor or diminishing its impact reflects the translator's approach and ideology as well as the variable degrees of willingness to enter - and let the target readers have access to - a different cultural system.

\section{References}

Aisenman, Ravid A. "Structure-Mapping and the Simile-Metaphor Preference." Metaphor and Symbol. Vol. 14, no . 1, (1999): 45-51.

Al-Zoubi Mohammad et al. "Cogno-Cultural Issues in Translating Metaphors." Perspectives: Studies in Translatology. Vol. 14, nº . 3, (2007): 230-239.

Anderson, Wendy et al. Mapping English Metaphor Through Time. Oxford: Oxford University Press, 2016.

Arrampicarsi. Treccani. Available at: http://www.treccani.it/vocabolario/ arrampicarsi/. Access in: 04 Out 2019.

Atkins, Peter. "Metaphors and Meanings in Modern Landscapes: Reading the Landscape". In: Atkins, Peter J.; Simmons, I.G; Roberts, B.K; Hodder, Arnold (Eds). People, Land and Time. 1998, p. 219-230.

Bridgeman, Teresa. "On the 'Likeness' of Similes and Metaphors (With Special Reference to Alfred Jarry's 'Les Jours et les nuits')". The Modern Language Review. Vol. 91, ${ }^{\circ}$. 1. (1996): 65-77. 
Calm. Oxford English Dictionary. Oxford: Oxford University Press. Available at: https://www.oed.com/view/Entry/26481?rskey=zZEJSY\&result=1\&isAdva nced $=$ false\#eid. Access in: 04 Out 2019.

Chiappe, Dan et al. "Reversibility, Aptness, and the Conventionality of Metaphors and Similes." Metaphor and Symbol. Vol. 18, nº. 2, (2003): 85-105.

Climb. Oxford English Dictionary. Oxford: Oxford University Press. Available at: https://www.oed.com/view/Entry/34342? rskey=hiBU3G\&result=2\&isAdva nced $=$ false\#eid. Access in: 04 Out 2019.

Cling. Oxford English Dictionary. Oxford: Oxford University Press. Available at: https://www.oed.com/view/Entry/34369?rskey $=$ Xm9So7\&result $=3 \&$ isAdva nced $=$ false\#eid. Access in: 04 Out 2019.

Cronin, Michael. Translation and Identity. Amsterdam: Routledge, 2006.

Dancygier, Barbara; Sweetser, Eve. Figurative Language. Cambridge: Cambridge University Press, 2014.

Deledda, Grazia, La Madre. Milão: Fratelli Treves Editore, 1920.

Deledda, Grazia. The Mother. Translator by Mary G Steegmann. New York: The MacMillan Company, 1928 [1923].

Douthwaite, John et al. (Eds). The stylistics of landscapes, the landscapes of stylistics. Amsterdam: John Benjamins Publishing Company, 2017.

Eco, Umberto. "Metafora e semiotica interpretativa". In: Marmo, Costantino; Bonfiglioli, Stefania. (Eds). Retorica e scienze del linguaggio: teorie e pratiche dell'argomentazione. Roma: Aracne, 2005, p. 407-437.

Eggan, Taylor A. "Landscape Metaphysics: Narrative Architecture and the Focalisation of the Environment." English Studies. Vol. 99, nº . 4, (2018): 398-411. 
Epley, Nicholas; Waytz, Adam; Cacioppo, John T. "On Seeing Human: A ThreeFactor Theory of Anthropomorphism." Psychological Review. Vol. 114, ${ }^{\circ}$. 4, (2007): 864-886.

Fill, Alwin; Mühlhäusler, Peter. (Eds). The Ecolinguistic reader. Londres: Continuum, 2001.

Gavins, Joanna; Lahey, Ernestine. "World Building in Discourse". In: Gavins, Joanna; Lahey, Ernestine. (Eds). World Building: Discourse in the Mind. Londres: Bloomsbury Publishing Plc. 2016.

Gibb, Heather; Wales, Roger. "Metaphor or Simile: Psychological Determinants of the Differential Use of Each Sentence Form." Metaphor and Symbolic Activity, Vol. 5, no. 4, (1990): 199-213.

Glucksberg, Sam; Haught, Catrinel. "On the Relation Between Metaphor and Simile: When Comparison Fails." Mind \& Language. Vol. 21, $\mathrm{n}^{\circ} .3$ June (2006): 360-378.

Goatly, Andrew. The language of metaphors. Amsterdam: Routledge, 1997.

Hough Carole. "The metaphorical landscape”. In: Anderson, Wendy; Bramwell, Ellen; Hough, Carole (Eds). Mapping English Metaphor Through Time. Oxford: Oxford University Press, 2016. Available at: https://mappingmetaphor.arts.gla. ac.uk/. Access in: 22/03/2019.

Johnson, Jane. "The use of deictic reference in identifying point of view in Grazia Deledda's Canne al Vento and its translation into English.". Target. Vol. 32, $\mathrm{n}^{\mathrm{o}}$. 1, (2011): 62-76.

Lahey Ernestine. "Megametaphorical mappings and the Landscapes in Canadian Poetry". In: Lambrou, Marina; Stockwell, Peter. (Eds). Contemporary Stylistics. Londres: Continuum, 2010, p. 156-167.

Lakoff, George; Johnson, Mark. Metaphors We Live By. Chicago: University of Chicago Press, 1980. 
Lakoff, George; Turner Mark. More Than Cool Reason: A Field Guide to Poetic Metaphor. Chicago: University of Chicago Press, 2009.

Magill, Frank Northen. The Nobel Prize Winners: 1901-1926. New York: Salem Press, 1987.

Mandelblit, N. "The cognitive view of metaphor and its implications for translation theory." Translation and Meaning. Part 3. Universitaire Press, (1995): 483-495.

Massaiu, Mario. La Sardegna di Grazia Deledda. Cagliari: Editrice sarda Fossataro, 1976.

Miccinesi, Mario. Grazia Deledda. Firenze: La Nuova Italia, 1975.

Mortara Garavelli, Bice. "La Lingua di Grazia Deledda”. In: Collu, Ugo. Grazia Deledda nella cultura contemporanea. vol. 2. Nuoro: Consorzio per la pubblica lettura S. Satta, 1992, p.115-131.

Newmark, Peter. Approaches to Translation (Language Teaching Methodology Series). Oxônia: Pergamon Press, 1981.

Prandi, Michele. "Typology of Metaphors: Implications for Translation." Mutatis Mutandis. Vol. 3, nº. 2, (2010): 304-332.

Prandi, Michele. "Translating Metaphors". In: Miola, Emanuele; Ramat, Paolo. (Eds). Language Across Languages: New Perspectives on Translation. Cambridge: Cambridge Scholars Publishing, 2015, p. 83-104.

Schäffner, Christina. "Metaphor and translation: some implications of a cognitive approach.” Journal of Pragmatics. vol. 36, (2004): 1253-1269.

Sconvolto. Grande dizionario della lingua italiana. Utet grandi opere. Imola: Battaglia Edittore. p. 195.

Shrill. Oxford English Dictionary. Oxford: Oxford University Press. Available at: https://www.oed.com/view/Entry/178871? rskey=0J7ngd\&result =2\&isAdva nced $=$ false\#eid. Access in: 04 Out 2019. 
Stern, Josef. Metaphor in Context. Massachusetts: MIT Press, 2000.

Werth, Paul. Text Worlds: Representing Conceptual Space in Discourse. Londres: Pearson Education Inc.,1999.

Whistle. Oxford English Dictionary. Oxford: Oxford University Press. Available at: https://www.oed.com/view/Entry/228547? rskey $=$ VGnahR\&result $=2 \&$ isAdv anced $=$ false\#eid. Access in: 04 Out 2019.

Zerkowitz, Judit. “'How Others See ...': Landscape and Identity in a Translated Poem by Radnóti”. In: Douthwaite, John; Virdis, Daniela Francesca; Zurru, Elisabetta. (Eds). The Stylistics of Landscapes, the Landscapes of Stylistics. Amsterdam: John Benjamins Pub. Comp., 2017, p. 81-93.

Recebido em: 22/01/2020

Aceito em: 16/03/2020

Publicado em maio de 2020

Eleonora Fois. E-mail: eleonora.fois@unica.it. ORCID: https://orcid.org/00000001-7802-6233. 